\title{
External and internal drivers for the water sector: global change and paradigm shift
}

\author{
S. Minar \\ Institute for Infrastructure and Resources Management, \\ University of Leipzig, Germany
}

\begin{abstract}
The water sector has become subject to significant shifts due to global change. That's why the break-up of the centrally dominated infrastructure needing to become more and more flexible in recent times is being discussed. Demographic, social and economic changes have led to a decrease in water demand and thus to an under-utilisation of the technical infrastructure. In contrast, the increase of heavy rains and prolonged dry periods has changed the sewage system contrarily. Furthermore, the legal requirements of the European Water Framework Directive (WFD) and its environmental objectives have to be observed. In the field of sewage disposal arises a paradigm shift from the central stormwater water disposal towards decentralised stormwater management to cope with the challenges. However, the integration of a decentralised approach to an existing centralised infrastructure system represents further challenges, especially due to heterogeneous inter- and intraregional settlement and infrastructure development.

Keywords: paradigm shift, decentralised stormwater management, disconnection of rainwater, sewage disposal, networked transformation, extensive/disperse dismantling, Cold Spots and Hot Spots, global change.
\end{abstract}

\section{Introduction}

In the past the entire water sector had to react to an increasing demand. The central infrastructure system was expanded continuously because of the growing system requirements. Under these conditions, it has economic and operational benefits over a decentralised approach. As a result, urban areas are characterised 
by a spacious centrally organised network of water infrastructure which consists of the drinking water pipeline, sewage canalisation and treatment systems. The technical infrastructure is characterised by a long-lasting operation time of 80 years or more. In addition, there are high investment costs with a share of fixed costs of $80 \%$ to $20 \%$ of variable costs.

In recent years, the requirements on the water sector have shifted due to external drivers. Consequently, in the field of sewage disposal (sewage and stormwater disposal) arise a paradigm shift from the central stormwater disposal towards decentralised stormwater management within urban areas [1]. This obvious different approach to dealing with stormwater requires a significant rebuilding phase of the existing infrastructure system; also called transformation [2]. In the case of a settlement expansion and new development, such infrastructure projects can be considered in planning processes, whereas in the case of existing settlement further technical and organisational challenges come up; especially in a mixed system.

Based on a literature review, it shall demonstrate a coherent status of research for the transformation of central stormwater disposal to decentralised stormwater management within existing settlement. First, there will be a short overview of the partially contrary influencing factors of the sewage disposal. Second, the new dealing with urban stormwater and their management objectives is summarised. Finally, the problem of integration of a decentralised approach in a centralised infrastructure system is demonstrated and discussed, focusing on the technical aspects of the transformation.

\section{Global change and its impacts on the urban water sector in Germany}

Global changes have changed the requirements on the water sector including the sewage treatment significantly in recent years (fig. 1). In Germany the forecast shows a decline in population from 80.5 million inhabitants to approximately 77.4 million inhabitants by the year 2030 and approximately 69.4 million inhabitants by the year 2050 [3]. Additionally, the demand for water has been decreasing from 147 1/pers. per day in 1990 to only 121 1/pers. per day due date because of increasing water-saving household appliances and tapwares as well as increasing environmental awareness. The industrial water demand has also been decreasing significantly over the years. Compared with this, the dimension of the sewage was constructed up to 219 1/pers. per day, which was based on water demand forecasts from the 1970s and 1980s [4]. The declining entire water demand - based on the demographic, social and economic changes - and the expectable increase in temperature and the prolonged dry periods due to climate change lead to an under-utilisation in mixed systems. As a result, the risk of deposit increases and the quality of wastewater declines by biochemical processes. Furthermore, there may be damage of cement-bounded materials of canalisation by the biogenic sulphuric corrosion and sulphides [5]. In addition, the positive economies of scale disappear due to declining water demand and the demographical induced declining customer number [6, 7]. Ergo, the specific and 


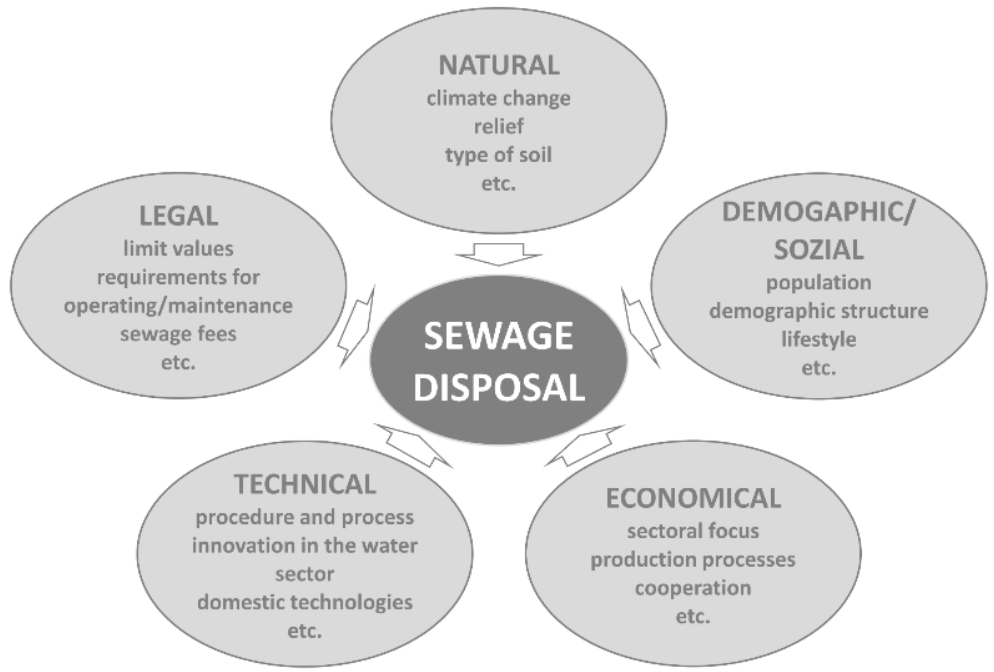

Figure 1: Influencing factors for the sewage disposal (based on $[17,18]$ ).

population-related costs rise continuously due to the high fixed costs of sewage disposal to maintain the infrastructure [8].

In contrast, a more frequent and stronger hydraulic load of the canalisation and sewage treatment plants is expected due to extreme precipitation; especially, by heavy rain [8]. In this context, Fuchs et al. [9] identify potential overwater areas by use of an examination for sewerage flooding for Dresden, Saxony. An increased of flood events can be expected, particularly, including an increase in heavy rain events in Saxony during the summer months [10]. Furthermore, the simulation results by Kuchenbecker et al. [11] point out a significant climateinduced increase in flood events of Hamburg's mixed sewage system. As a result, performance losses by the sewage and stormwater treatment systems cannot be excluded [12] as well as other infrastructural failures [13]. Consequently, more and more backwater, overwater and flooding phenomena take place in urban areas, which can lead to significant damage in agglomerations $[8,14]$. According to German insurance companies, about half of the regulated flood damage caused by such localised extreme events nowadays [15].

The ecological requirement increase due to WFD and its environmental objectives taking the cost for the water services into consideration. It should be noted that the definition of water pricing has to take into account the cost-bycause and cost covering principle as well as the economic costs to cover the respective water services together with the environmental and resource costs [16].

Especially the dominant central organised water infrastructure appears to be inflexible towards changes due to its unique features. Additionally, it is influenced by global change depending on the locality, settlement and landscape 
structure, and their highly heterogeneous characteristics. Consequently, mesoscale disparities do not occur only in regional but also within urban areas with the result that sections of the water sector are involved very differently [6].

\section{Paradigm shift: breaking new soil in dealing with the stormwater within urban areas}

A paradigm shift in the field of sewage disposal arises due to global change [1]. While currently the rain water is removed completely and as quickly as possible through the central mixed or separation system analogously to the sewage disposal, the new discussion focuses on the advantages of local stormwater management considering the existing drainage service (flooding and waterlogging protection) [19].

The fundamental functional task of stormwater management is to store stormwater as locally as possible, treat or clean, and/or derive throttled [20]. The effectiveness of the stormwater management systems are depending on the natural condition of the soil, the occurrence of contaminated sites [21, 22], anthropogenic above- and underground development [23], and of the global influencing factors.

By now the stormwater management can look back on over 25 years of practical experience and a variety of (pilot) projects, which demonstrate the functionality and adherence to the state-of-the-art [1, 19]. The essential management objectives can be extracted from fig. 2. According to Sieker and Sieker [24], stormwater can be managed within the built-up area in this way that the remaining annual runoff is equivalent to the condition before development or close to it. The resulting reduction of negative impact on the natural water balance can be guaranteed by maintaining the existing drainage service.

By reducing the stormwater runoff within the canalisation, it enables the reduction of the dimensioning or even the dismantling of the canalisation [25]. Consequently, long-term infrastructural adaptation measures are preferred in regards to the declining water demand. In this context, the treatment-free

\footnotetext{
MAINTENANCE OF NATURAL HYDROLOGICAL REGIME

- reduction of negative effects on natural hydrological regime

IMPROVEMENT OF WATER QUALITY

- reduction of material entries in waters

- reduction the volume of stormwater runoff

- minimising the hydraulic load

- reduction of peak runoff
}

MAINTENANCE OF EXISTING DRAINAGE COMFORT

- flooding/waterlogging protection

INFRASTRUCTURAL ADAPTION MEASURES

- smaller dimensioning/ dismantling of canalisation

- procedural adaption potentials in sewage treatment

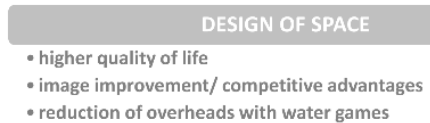

Figure 2: Categories of the essential management objectives for decentralised stormwater management (based on [27]). 
stormwater runoff has not processed the sewage treatment plants unnecessarily. Furthermore, resulting procedural adaptation potentials of sewage treatments [26].

\section{Structural challenges through an integrating of stormwater management systems within existing settlement}

The decentralised approach dealing with stormwater requires a transformation of the existing centralised infrastructure system. Technical and organisational challenges result during the effective as well as cost-effective integration of alternative and complementary technologies into existing systems [2].

According to Koziol [6] the central system is still required by an integration of stormwater management systems (substitution), with the result that the utilisation will further reduce. Moreover from a technical perspective, a network transformation is problematic because single projects have no greater reaction on the existing networks and facilities. Especially taking individual network components out from the total network is only possible under certain conditions. Complex interactions between various systems and their innovations make even systemic changes in urban areas more complicate, where most of the networks are depreciated. Ergo, to this day, the adaptations of the technical sewage infrastructure followed the two criteria [6]:

1) Condition compact, dense settlement structure by housingeconomical/urban adaptation strategies, meaning dismantling from outside to inside and cost-effective continued operation of existing centralised networks and facilities

2) Avoidance of adaptation investments in the phases of shrinking by adapting for a network structure urban redevelopment planning

These criteria shall be assessed critically because of the already described global influences on the sewage infrastructure. The current continual trend of shrinking areas as well as the general declining water demand requires adaptation measures in periods of shrinking, too. In this context, the settlement dismantling is another challenge. The (partial) dismantling measures of the building stock alone will influence the functionality of the technical infrastructure significantly. Fig. 3 illustrates extensively the two main basic variants of settlement dismantling that are considered and described below.

Using the extensive dismantling will demolish whole settlement units. Normally there are no main problems expected from the perspective of water infrastructure because the network is dismantled opposite to its development as part of the demolition building. Alternatively, parts of the main network can also be decommissioned. At the edge of service area a dismantling/decommissioning of a part of the main network is even possible. However, an extensive dismantling within a settlement requires a transit route for supply maintenance located behind residential areas or single buildings [6].

Among disperse dismantling is be understood the floor-by-floor dismantling and selective demolition. At the floor-by-floor dismantling the structure and length of the network will remain, but leads to a higher allocation of fixed costs 
and replacement investment for network renovations. If the canalisation becomes under-utilised, the operating costs will escalate. Moreover, other investments can become to adapt the dimension of the canalisation and treatment systems. Although by the selective dismantling of individual buildings are removed from the building block, the effects are comparable to the floor-by-floor dismantling $[6,28]$.

Koziol [6] points out that the immobile characteristics of the water infrastructure lead to a reduction of facilities and a re-use elsewhere is technically or cost-effective hardly possible. In the case of permanent decommissioning, the existing amortised costs of these facilities and networks have to be amortised prematurely and will more burdening of business. More cost of dismantling or protection exposed facilities/networks cannot ruled out. After Naumann and Wissen [29] inter- and intraregional spatial differentiations may increase the cost burden again. Furthermore, an integration of decentralised systems in a centralised system can further increase the fixed costs due to maintenance the system function of the entire system. This extends to transitional phases within a transformation process. As a result, operators have little willingness towards a transformation and comprehensive system exchanges will be prevented $[6,30]$.

Consequently, a system exchange within existing settlement will be possible and useful especially, if the existing system needs to be significant more expensive (fixed cost case), or if necessary, replaced prematurely, because of functional problems by shrinking processes. Specifically, this means that transformation processes are interesting in low population density settlement areas with relevant shrinking phenomena especially. But now they are usually associated with a high rate of destruction of capital and may be with significant

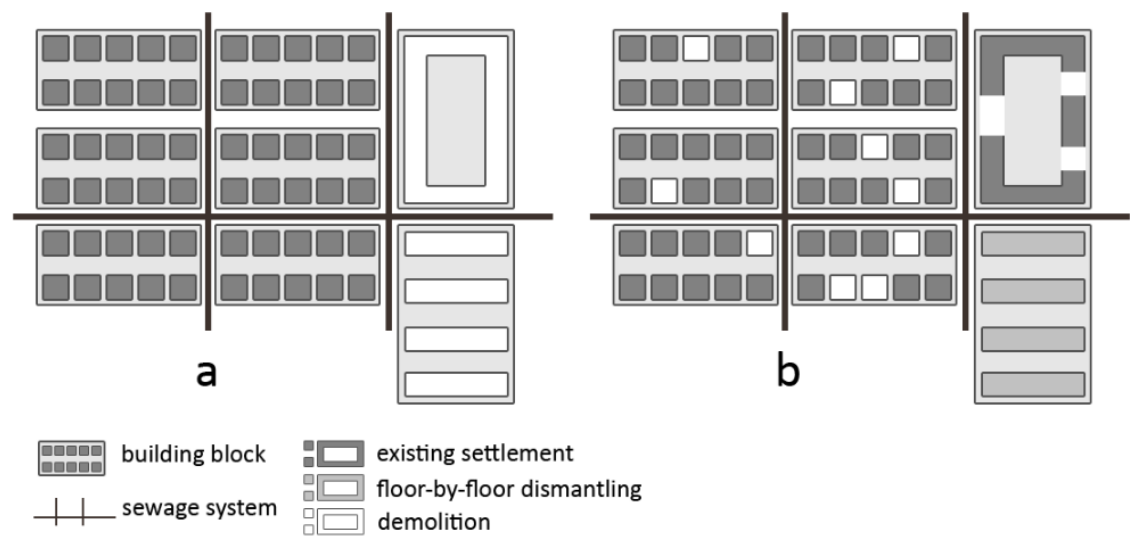

Figure 3: Basic variants of the dismantling of urban redevelopment: (a) extensive dismantling; (b) disperse dismantling (based on [28]). 
problems in the remaining networks. System exchanges in inner-city locations are attractive relatively, but there are spatial problems caused by lack of available space and structural requirements [6].

In the long term low costs are expected for an extensive dismantling, whereas denser compared to more sparsely populated settlement structures are favoured $[6,28]$.

Basically, reducing of future costs cannot be excluded by further learning and economical scales. First cost reductions between 1985 and 2002 were already demonstrated in decentralised systems as well as in membrane systems [31].

Schiller [7] points out the inefficiency of a short-term dismantling of the central system. But he emphasises that in the long term a system exchanges under coordination between the water sector and the settlement planning leads to saving potentials. Furthermore, integrating other infrastructures could create further positive effects. For example, using decentralised sewage treatment plants can contribute to overcome the challenges for the water sector [26], which are recognised as a full-value substitute for central sewage treatment plants since 2002 nationwide in Germany. An interaction with the stormwater management cannot be excluded. The literature shows that combinations of traditional and future-oriented approaches do not require a turning away from the traditional system [30, 32]. Furthermore, it is important to note that usually technical developments do not happen independently from one another, in order that innovation are not only cause synergy effects but also contrary $[18,30]$.

Last but not least, it should be noted that spatially and socially disparities in the water sector can be caused by emerging fragmented and spatially differentiated infrastructure development, so-called Cold Spots and Hot Spots. The Cold Spots are structurally weak areas with a secondary interest for operators, whereas Hot Spots are structurally strong and developable areas. For operators it is more favourable to avoid less lucrative areas as well as social groups and to provide more profitable and customised services for selected groups of customers [33, 34]. Cold Spots and Hot Spots occur usually inter- and intraregional dispersed and some areas are also characterised with the properties of both types due to time disparities (e.g. seasonal tourism) [33]. At the moment only the drinking water supply and sewage disposal are part of the public services, while (local) water utilities and urban planning do not have to take care of a comprehensive equivalent integration of the stormwater management. However, the theory of Cold Spots and Hot Spots is also useable for the stormwater management and not only for drinking water supply and sewage disposal. This can be derived amongst others by the already described different economic incentives between strong and weak structural areas next to maintenance the operability of technical facilities with global change in mind.

\section{Discussion and outlook}

The technical infrastructure is concerned of heterogeneous and partly contrary acting consequences (such as under- and over-utilization of sewage) because of the extreme heterogeneous interactive global change on sewage disposal. 
Additional inter- and intraregional differences magnify the problem. According to general statements, consequences of global change and its solutions appear difficult to realise, while adaption at the regional level implicate a significantly higher effort.

Previous studies have been able to show that a decentralised stormwater management can contribute to overcome the challenges essentially as part of a transformation process within the urban areas. The disconnection of the stormwater and the associated discharge of sewage make long-term interventions in the sewage infrastructure possible. But the fact is that possible strategies in adapting the water infrastructure can only be implemented elaborately. For instance a dismantling/decommissioning of the canalisation is preferably from outside to inside. Compared to the centralised approach, the decentralised approach can react more flexible to changes.

The focus on adaptation measures within compact and dense settlement structure and the avoidance of adaptation investments in the phases of shrinking is no longer in keeping with the times. Especially since shrinking regions are not single-handedly experiencing water-related effects caused by demographic, social and economic changes. Koziol et al. [5] suggest that stable and growing regions need to prepare currently for future shrinking processes. The specific water demand decreases mostly independent from the population development because beside the emerging demographic and steady economic change. Consequently, the challenge is to meet the requirements and, if necessary, to avoid or to minimise overloads and canalisation under-utilisation in the future [35].

Early research by the author point out, stormwater management has been mostly integrated into new developed areas and less in existing settlement. In addition, these integrations are often via pilot projects or within individual projects. Innovative concepts for a safe and adaptable stormwater management within the project dynaklim in North Rhine-Westphalia [36] or the project RISA (Rain InfraStructure Adaption) in Hamburg [37] are ones of these. The previous reserved integration within existing settlement illustrates the importance of a multi-structural cooperation with the affected institutions and the public. This is documented by the studies of Wolff and Marschke [38] and Marschke et al. [39], who used the example of programmes on urban restructuring in Saxony, Eastern Germany, to show that provided subsidies for infrastructural adaptation of sustainable urban planning could not be retrieved in time.

It seems necessary to use geodata more often, with the aim to develop extensive-effective instruments for a medium and long term integrating of an extensive stormwater management within existing settlement. Geiger et al. [22] introduced a GIS-based method for potential analysis of urban stormwater management depending on natural conditions and urban structure types (UST).

In the case of integration of stormwater management within existing settlement, a modification of the methodology appears to be necessary. For this purpose, targets are currently being developed, which first of all can be derived from the six categories of management objectives to meet the ecological requirements of the WFD. In the context of settlement and infrastructure 
development also occurring Cold Spots and Hot Spots have to be identified and considered. It can be assumed that investment are made in the economical attractive Hot Spots especially, during Cold Spots are interesting for the technical feasibility.

The aim is to generate disconnection potential types, which can illustrate a ranking of disconnection areas depending on emphasis. As a result, a transparent and coherent concept for the integration of stormwater management in existing settlement can be developed. Ultimately, multi-structure statements can be created, which may be used as a basis for targeted economic discussions [40]. Consequently, existing economic instruments and their effect of stormwater management can be discussed and new approaches can be demonstrated.

\section{References}

[1] Sieker, F., Sieker, H., Zweynert, U., Zhengyue, J., Paradigmenwechsel in der Siedlungswasserwirtschaft beim Umgang mit Regenwasser, GWF Wasser/Abwasser, Bd. 149/7/8, DIV - Deutscher Industrieverlag GmbH, pp. 558-570, 2008

[2] Kluge, T., Libbe, J., Transformation netzgebundener Infrastruktur. Strategien für Kommunen am Beispiel Wasser, Berlin, Difu, 420 p., 2006

[3] DESTATIS, 12. koordinierte Bevölkerungsvorausberechnung. Bevölkerung Deutschlands bis 2060, DESTATIS - Statistisches Bundesamt, Wiesbaden, 50 p., 2009

[4] BDEW, Wasserfakten im Überblick. Stand: April 2012, BDEW Bundesverband der Energie- und Wasserwirtschaft e.V., 2012

[5] Koziol, M., Veit, A., Walther, J., Stehen wir vor einem Systemwechsel in der Wasserver- und Abwasserentsorgung? Sektorale Randbedingungen und Optionen im stadttechnischen Transformationsprozess, Berlin, Dt. Inst. für Urbanistik, 148 p., 2006

[6] Koziol, M., Transformationsmanagement unter den besonderen Bedingungen der Schrumpfung, Transformation netzgebundener Infrastruktur. Strategien für Kommunen am Beispiel Wasser, eds. Kluge, T., Libbe, J., Difu, pp. 355-400, 2006

[7] Schiller, G., Dezentralisierung von Abwassersystemen, wwt Wasserwirtschaft, Wassertechnik. Das Praxismagazin für die Trink- und Abwassermanagement, issue 5, HUSS MEDIEN GmbH, pp. 38-41, 2012

[8] DWA - Deutsche Vereinigung für Wasserwirtschaft, Abwasser und Abfall, Klimawandel - Herausforderungen und Lösungsansätze für die deutsche Wasserwirtschaft, Hennef. DWA, 32 p., 2010

[9] Fuchs, L., Lindenberg, M., Männing, F., Schmitt, T. G., Überflutungsprüfungen im Rahmen der generellen Entwässerungsplanung in der Stadt Dresden, KA - Korrespondenz Abwasser, Abfall, Bd. 56/4, DWA, pp. 358-364, 2009

[10] SMUL, Klimawandel in Sachsen. Sachstand und Ausblick 2005, SMUL Sächsisches Staats-ministerium für Umwelt und Landwirtschaft. 111 p., 2005 
[11] Kuchenbecker, A., Bischiff, G., Ziegler, J., Krieger, K., Verworn, H.-R, Auswirkungen des Klimawandels auf das Hamburger Kanalnetz, $K A-$ Korrespondenz Abwasser, Abfall, Bd. 57/9, DWA, pp. 874-881, 2010

[12] Sartor, J., Die Wahrscheinlichkeit des gleichzeitigen Auftretens maßgebender Abflußereignisse in Kanalisationsnetzen und natürlichen Gewässern, Universität Kaiserslautern, 131 p., 1994

[13] Lindenberg, M., Hochwasserschutz für Kanalnetze. Anforderungen und Beispiele, 36 p., 2009

[14] Richters, L., Wagner, C., Langfristige Entwicklung der Wasserabgabe Prognosemöglichkeit mittels historischer Daten, GWF - Wasser/ Abwasser, Bd. 152/3, DIV - Deutscher Industrieverlag GmbH, pp. 262267, 2011

[15] Illgen, M., Starkregen und urbane Sturzfluten. Handlungsempfehlungen zur kommunalen Überflutungsvorsorge, Wasser und Abfall. Boden Altlasten - Umweltschutz, Bd. 150/10, BKW - Bund der Ingenieure für Wasserwirtschaft, Abfallwirtschaft und Kulturbau e. V., pp. 10-16, 2013

[16] KA, Deckung der Kosten der Wasserdienstleistungen nach Artikel 9 Wasserrahmenrichtlinie - Teil 2, KA - Korrespondenz Abwasser, Abfall, Bd. 60/2, DWA, pp. 103-110, 2013

[17] Tränckner, J., Franz, T., Winkler, U., Obermayer, A., Frehmann, T., Jathe, R., Freymuth, J., Wirtschaftliche Auswirkungen veränderlicher Rahmenbedingungen auf Abwasserentsorgungsunternehmen, $K A-$ Korrespondenz Abwasser, Abfall, Bd. 60/2, DWA, pp. 111-120, 2013

[18] Freymuth, J., Franz, T., Frehmann, T., Jathe, R., Obermayer, A., Tränckner, J., Winkler, U., Wirtschaftliche Auswirkungen struktureller Veränderungen - ein Blick von oben, KA - Korrespondenz Abwasser, Abfall, Bd. 58/2, DWA, pp. 159-164, 2011

[19] Sieker, F., Sieker, H., Zweynert, U., Konzept für bundeseinheitliche Anforderungen an die Regenwasserbewirtschaftung, UBA Umweltbundesamt, Dessau-Roßlau, 72 p., 2009

[20] Sieker, F., Grottker, U., Hagendorf, U., Hahn, J., Sieker, H., Sommer, H., Wassermann, H., Anforderungen und Zielgrößen für eine zeitgemäße Regenwasserbewirtschaftung, GWF - Wasser/Abwasser, Bd. 145/12, DIV - Deutscher Industrieverlag GmbH, pp. 874-880, 2004

[21] Fryd, O., Backhaus, A., Birch, H., Fratini, C. F., Ingvertsen, S. T., Jeppesen, J., Panduro, T. E., Roldin, M., Jensen, M. B., Water Sensitive Urban Design Retrofits In Copenhagen - 40\% To The Sewer, 60\% To The City, Water Science \& Technology, Bd. 67/9, IWA Publishing, pp. 19451952, 2013

[22] Geiger, W. F., Dreiseitl, H., Stemplewski, J., Neue Wege für das Regenwasser. Handbuch zum Rückhalt und zur Versickerung von Regenwasser in Baugebieten, München, Oldenbourg-Industrieverlag, 256 p., 2009 
[23] Fach, S., Stubbe, H., Wasserdurchlässig befestigte Verkehrsflächen als Beitrag für ein ganzheitliches Entwässerungskonzept in urbanen Gebieten, GWF - Wasser/Abwasser, Bd. 149/4, DIV - Deutscher Industrieverlag GmbH, pp. 338-347, 2008

[24] Sieker, F., Sieker, H., Reformschritte zu einem Paradigmen- und Systemwechsel bei der Regenwasserbewirtschaftung. Teil I: Regenwasserbewirtschaftung im Rahmen des neuen Wasserhaushaltsgesetzes, bundeseinheitliche Anforderungen, Eigenschaften und Wirkungen des dezentralen Prinzips, GWF Wasser/Abwasser, Bd. 150/10, DIV - Deutscher Industrieverlag GmbH, pp. 796-802, 2009

[25] Matsushita, J., Ozaki, M., Nishimura, S., Ohgaki, S., Rainwater Drainage Management For Urban Development Based On Public-Private Partnership, Water Science \& Technology, issue 2/3, IWA Publishing, pp. 295-303, 2001

[26] Zech, T., Entwicklung eines semidezentralen Verfahrens für kommunales Abwassermanagement und Erprobung in der großtechnischen Anwendung, IGB - Frauenhofer-Institut für Grenzflächen- und Bioverfahrenstechnik, Stuttgart, 171 p., 2008

[27] Minar, S., Externe und interne Treiber für den Wassersektor: Globale Veränderungen und Paradigmenwechsel, University of Leipzig, unpublished

[28] Koziol, M., Räumliche Differenzierung der Infrastrukturversorgung. Chancen und Restriktionen im Rahmen des Stadtumbaus, Infrastrukturnetze und Raumentwicklung. Zwischen Universalisierung und Differenzierung, eds. Moss, T., München, Oekom, pp. 173-186, 2008

[29] Naumann, M., Wissen, M., Neue Räume der Wasserwirtschaft. Untersuchungen zur Trinkwasserver- und Abwasserentsorgung in den Regionen München, Hannover und Frankfurt (Oder), Berlin, Dt. Inst. für Urbanistik, 79 p., 2006

[30] Sartorius, C. M., Hillenbrand, T., Ausbreitung dezentraler Ansätze der Abwasserbehandlung und des Regenwassermanagements im Elbegebiet, KA - Korrespondenz Ab-wasser, Abfall, Bd. 55/10, DWA - Deutsche Vereinigung für Wasserwirtschaft, Abwasser und Abfall, pp. 1086-1094, 2008

[31] Knopp, A., Marktentwicklungen und ökonomische Randbedingungen alternativer Technikbausteine im Bereich der Wasserver- und Abwasserentsorgung, Fraunhofer Institut für System- und Innovationsforschung, Karlsruhe, 2004

[32] Stemplewski, J., Becker, M., Raasch, U., Niederschlagswasser bewirtschaften statt beseitigen - ökologisch und wirtschaftlich sinnvoll, KA - Korrespondenz Abwasser, Abfall, Bd. 57/10, DWA, pp. 1011-1019, 2010

[33] Naumann, M., Neue Disparitäten durch Infrastruktur? Der Wandel der Wasserwirtschaft in ländlich-peripheren Räumen, München, Oekom, 282 p., 2009 
[34] Moss, T., Zwischen Ökologisierung des Gewässerschutzes und Kommerzialisierung der Wasserwirtschaft: Neue Handlungsforderungen an Raumplanung und Regionalpolitik, Raumforschung und Raumordnung, Bd. 67/1, Springer Verlag, 2009

[35] Bellefontaine, K., Breitenbach, H., Auswirkungen der demografischen Entwicklung auf die Gebührenkalkulation und die Gebührenentwicklung in der Wasserwirtschaft, KA - Korrespondenz Abwasser, Abfall, Bd. 55/9, DWA, pp. 996-1001, 2008

[36] Dynaklim, E3.2 Innovative Konzepte für eine sichere und anpassungsfähige Regenwasserbewirtschaftung, http://www.dynaklim.de

[37] Hamburg Wasser, RISA- das Gemeinschaftsprojekt zur Umsetzung einer zukunftsfähigen Regenwasserbewirtschaftung in Hamburg, http://www.risa-hamburg.de/index.php/hintergrund-ziele.html

[38] Wolff, M., Marschke, L., Stadtumbau und Stadttechnik (Teil 7). Langfristige Infrastrukturelle Entwicklungsplanung - ISEP, Förderpolitk, Leitfaden, ein Anwendungsbeispiel aus Zittau, wwt (Hrsg.): wwt Wasserwirtschaft, Wassertechnik. Das Praxismagazin für die Trink- und Abwassermanagement, issue 5, HUSS MEDIEN GmbH, pp. 54-59, 2008

[39] Marschke, L., Bräuninger, S., Böhnisch S., Stadtumbau und Stadttechnik (Teil 6). Der Infrastrukturelle Entwicklungsplan (ISEPC) - weitere Anwendungsbeispiele aus Merseburg und Riesa, wwt - Wasserwirtschaft, Wassertechnik. Das Praxismagazin für die Trink- und Abwassermanagement, issue 10, HUSS MEDIEN GmbH, pp. 50-54, 2007

[40] Geyler, S., Bedtke, N., Gawel, E., Nachhaltige Regenwasserbewirtschaftung im Siedlungsbestand. Teil 1: Ziele, Optionen und Herausforderungen, GWF - Wasser/Abwasser, Bd. 155/1, DIV Deutscher Industrieverlag GmbH, pp. 96-108, 2014 